\title{
ON THE TRADE-OFF BETWEEN THE RIGHT OF A DISABLED PERSON TO LIVE IN AN ACCESSIBLE ENVIRONMENT AND THE OBLIGATION TO PROTECT IMMOVABLE MONUMENTS IN POLISH LAW*
}

\author{
Tomasz Sienkiewicz** \\ The John Paul II Catholic University in Lublin
}

\section{Abstract}

The focus of this article is the competition of values that exists in the Polish legal system regarding adjustment of historic buildings to the needs of persons with disabilities. This is yet another case of the legal problem of choosing the superior value in the application of law. Numerous examples of situations in which friction between two competing values gives rise to practical problems are associated with subsidizing the removal of architectural barriers in listed historical buildings or heritage areas to meet the individual needs of persons with disabilities. On the one hand, there is the value of accessibility of buildings to the disabled, and on the other, there is the value of protection of monuments. The individual right of a person to free access to buildings is in competition with the right of the national community to respect the national heritage.

KEYwORDS: disabled person, administrative law, monument, human rights.

\section{EL DERECHO DE UNA PERSONA CON DISCAPACIDAD A VIVIR EN UN ENTORNO DE FORMA FUNCIONAL Y LA OBLIGACIÓN DE PROTEGER LOS MONUMENTOS INMUEBLES EN LA LEGISLACIÓN POLACA}

\section{RESUMEN}

En este artículo, el autor desea interesar al lector con el problema de la competencia de valores en el sistema legal polaco que se produce al adaptarse los monumentos históricos a las necesidades de los minusválidos. Muchas veces existe un problema legal de elegir un valor superior en la aplicación de la ley. Por ejemplo, cuando se subvenciona la eliminación de barreras arquitectónicas en relación con las necesidades individuales de personas con discapacidad, la situación es tal que cuando una persona discapacitada vive en un edificio inscrito en el registro de monumentos o en un edificio ubicado en un área inscrita en el registro de monumentos, surgen varios problemas prácticos, porque hay dos valores que compiten. Por un lado, el valor de la accesibilidad a las instalaciones de construcción para personas con discapacidad, por el otro, la protección de los monumentos. El derecho humano individual a la disponibilidad y accesibilidad de objetos de construcción compite con el derecho de la comunidad nacional a respetar el patrimonio nacional.

Palabras Clave: personas con discapacidad, minusválidos, derecho administrativo, monumento, derechos humanos. 
On 27th October 2017, a scientific conference was held at the John Paul II Catholic University of Lublin (KUL) ${ }^{1}$ to commemorate the 5 th anniversary of ratification by Poland of the Convention on the Rights of Persons with Disabilities. The event was co-organized by KUL, the Ministry of Family, Labour and Social Policy, and the State Fund for Rehabilitation of Disabled Persons. One of the subjects frequently discussed at the conference was accessibility of buildings to people with disabilities (Panel I on Public Space and Universal Design). The discussions demonstrated the relevance of this topic and the need for disseminating it in the academic community. And since the Convention is an international document, the problems of accessibility of public space to people with disabilities should not only be studied from the point of view of the national law, but also from the point of view of measures developed in this regard by other countries. Comparative studies and analyses should be carried out to investigate the possibilities of incorporating the best measures available into national systems, even though it is not always effective or possible to copy legal solutions from one country to another.

The focus of this article is the competition of values that exists in the Polish legal system regarding adjustment of historic buildings to the needs of persons with disabilities. This is yet another case of the legal problem of choosing the superior value in the application of law. Numerous examples of situations in which friction between two competing values gives rise to practical problems are associated with subsidizing the removal of architectural barriers in listed historical buildings or heritage areas to meet the individual needs of persons with disabilities. On the one hand, there is the value of accessibility of buildings to the disabled, and on the other, there is the value of protection of monuments. The individual right of a person to free access to buildings is in competition with the right of the national community to respect the national heritage.

Before discussing these values in detail, the question should be asked why we should be discussing the rights of persons with disabilities in the first place? Isn't the emphasis on the rights of this part of society exaggerated in the present times? Is it not a reaction against the evil that does not exist? Unfortunately, there are still

* The article was written as part of the project entitled "Prawne formy działania wojewódzkiego konserwatora zabytków" ("Legal acts of the provincial monument conservator," Reg. no. 2015/19/B/HS5/02525) within the framework of which research was funded by the National Science Centre, Poland (Narodowe Centrum Nauki). Quotations in the article, translated by the author into English, come from sources published in Polish. The term "provincial monument conservator" can also be translated into English as "voivodeship inspector of monuments," "Provincial Heritage Conservation Officer." Compare e.g. an English translation of the art 89 point 2 of the Act of 23 July 2003 on the protection and guardianship of monuments; on the Internet at: http://www.unesco.org/ culture/natlaws/media/pdf/poland/poland_act2302003_entof.pdf [Access: 10-12-2015-attentioninvalid legal status of the act].

** Doctor habilitatus in law, assistant professor in the Department of Administrative Law, Faculty of Law, Canon Law and Administration, The John Paul II Catholic University in Lublin; a Legal Counsel.

${ }^{1}$ Universidad Católica de Lublin Juan Pablo II. 
countries whose legislative systems do not respect human life as it is. In the history of humanity, there have already been states that did not observe the rules of human life. The important issues here are the world view and the philosophy of the functioning of the state, which either take into account the rules governing human life or not. Of special importance are the values respected in the legal system, as there does not exist a country with no value system. Most often, such systems are related to the dominant religion in the given territory. Even a state that declares itself completely separate from any church has a system of values that are enforced by the law. In the Polish doctrine, this dependence on axiology has been noted by many authors. For example, Łączkowski notes that "no state is able to avoid entering the fundamental domains of axiology, and therefore it always follows a certain world view. $^{2 \text { " }}$ There is no state whose legal system does not serve the realization of values. Some values are always there. They may be morally good or morally wrong. To say more, the law always expresses a view on the human being. Civil law (ius civile) expresses the sovereign's will and puts values into effect in social life. Sometimes the law embodies two different values which are morally good, and the realization of which requires balancing the scope of each of them in relation to specific facts.

To act in accordance with the law is therefore to act in such a manner so as not to rely merely on the unreflective execution of the formula contained in the law; the correct legalistic attitude in the application of the law takes into account

2 Łączkowski, W., Ograniczenia prawa stanowionego. [in:] Dęвı́́sкi A., Pomorska A., SMoleń, P. (eds.) W stużbie nauki prawa finansowego. Jubileusz obecności profesora Jana Gtuchowskiego w Katedrze Finansów i Prawa Finansowego Katolickiego Uniwersytetu Lubelskiego Jana Pawta II. Wydawnictwo KUL, Lublin, 2010, p. 71; cf. ŁĄCZKowsкI, W., Prawo a zmiana ustroju państwa. Wydawnictwo Naukowe Uniwersytetu Adama Mickiewicza, Poznań, 1992; ŁĄCzKowski, W., Granice prawa. [in:] Depo, W., Leszczyński, M., Guz, T., Marzec, P. (eds.), Veritatem in Caritate. Ksiegga Jubileuszowa z okazji 70. urodzin Ksiedza Biskupa Profesora Jana Śrutwy. Wydawnictwo KUL, Lublin, 2011, pp. 447-457; cf. on the influence of values on rationality of administrative decisions in: Sienkiewicz, T., Racjonalność decyzji administracyjnej. [in:] Marzec, P. (ed.), Servire veritati. Księga jubileuszowa z okazji siedemdziesiatych urodzin Profesora Kazimierza A. Ktosińskiego. Wydawnictwo KUL, Lublin, 2011, pp. 544-545. ZDYB, M., "Państwo prawa w perspektywie zaszłości historycznych oraz dokonujących się zmian.” [in:] Fundow ICz, S. (ed.) Wspótczesne problemy prawa publicznego. Studia z prawa publicznego, vol. 1, Lublin, 1999, p. 21; Cf. ZDYB, M., Prawny interes jednostki $w$ sferze materialnego prawa administracyjnego. Studium teoretyczno-prawne. Wydawnictwo Uniwersytetu Marii Curie-Skłodowskiej, Lublin, 1991, pp. 75-76. "Each legal norm has two sides: the essential one associated with literal wording of legal regulations and the existential one, which arises in relation to: a) axiological basis of the applicable legal system, natural order of things (natural law), principles of justice, righteousness of will, sense of law, etc.; b) facts of the case, to which law refers; c) supra-system norms, rules and principles which are a result of the civilization development (technical norms and standards, knowledge standards, praxeological principles, etc.); d) practices of law application (e.g. judicial decisions); e) doctrine views. A role of the organ of the state applying law is to identify the legal norm by referring not only to the situation and principle of conduct determined in a specific editing unit, but also by deducing a legal norm, taking into consideration the whole existential side of the legal rule and all-system rules. In such a reference system, each legal norm will be a system norm, and not a mechanical rule functioning separately from other rules, with the rejection of integrating values." 
the values conveyed in it. ${ }^{3}$ It is therefore important to verify which values related to the exercise of the rights of the disabled as well as the protection of heritage can be found in the Polish legal system. The Preamble to the Polish Constitution already states, among other things, that, we are to be "beholden to our ancestors for their labours, (...) for our culture rooted in the Christian heritage of the Nation and in universal human values," and also that we are "... obliged to bequeath to future generations all that is valuable from our over one thousand years' heritage," which is a direct reference both to Christian heritage and universal human values. Taking this into account, it should be noted that the circle of Christian culture embraces:

1. Respect for human life.

2. Respect for human heritage, especially national heritage, which, by virtue of its role of strengthening national identity, should be protected by the law of each State. ${ }^{4}$

In addition, attention should be paid to the rules related to the human life itself. The basis of human rights is dignity. An additional justification for human rights are the regularities of human life. Human beings do not create these regularities but only discover them, find that they exist $-\mathrm{a}$ fact from which the human rights of the disabled can be derived. The mode of human existence should also be the basis for the introduction of human rights into the legal system (positivism).

There is therefore a need to ask the question whether every human being is always fully functional (abled)? What are the criteria of "complete functionality?" This is not an analysis of the legal concept of "disabled person," but an attempt to answer the question whether human existence is characterized by periods of incomplete functionality. The question of disability is the question of the mode of human existence, also as a biological being subject to the laws of nature. The mode of human existence involves periods when the human being needs the help of others. No one is self-sufficient. Since in the course of human existence there occur periods when one needs the support of others (childhood, old age, sickness, etc.), this social dimension of human functioning has to be taken into account by those who govern the community. One should point out the regularities of human life associated with the dilemma indicated in the title of this article. This is not an exhaustive list of rules, of course, but an indication of those that are most relevant to the subject.

It should be noted that periods of incomplete functionality are part of human life. So the human rights of the disabled are simply human rights. We call them the rights of people with disabilities, to better accent them, but disability potentially affects every person as a biological being. In addition, every human being faces the

3 Cf. Ziembiński, J., Wstęp do aksjologii dla prawników. Wydawnictwo Prawnicze, Warszawa, 1990, p. 135 - "It turns out that legalism cannot in fact be treated as a purely formal attitude, for in speaking of respecting the law we speak of respecting a law that holds in regard certain fundamental values."

${ }^{4}$ Comp. Cf. Constitution of the Republic of Poland, art. 6, section 1. 
risk of losing fitness, because a person is unable to maintain total control over sudden events or processes (especially those initiated during the early period of life as a defenseless child). In the context of this topic, it is important to note the fact that inherent to human life is creative ability and some of the manifestations of this creativity become important to the whole national community due to social interest.

In connection with the above mentioned rules, the following questions should be asked:

- Do legal norms protect the life of the human being or the "superior human being?" - Can any life be "a life unworthy of living?"

A suitable example here is that of Nazi terror against mentally ill people. "From 1939 to 1941 more than 100 thousand mentally ill German citizens died in gas chambers 5 . Cases of murdering mental patients also occurred in the period in which Art. 211 of the Penal Code, which provided for the death penalty for a premeditated killer $^{6}$ (as amended by the Act of 4 September 1941) was in force.

Taking the above into account, the separation of the rights of people with disabilities is not a defense against the utopian state nor a theoretical hypothesis. Unfortunately, it has been experimentally tested how a state that does not respect in its actions the regularities of human life as it is acts? For this reason, to speak of the rights of people with disabilities is not speaking in exaggerated terms or speaking against an evil that does not exist, but rather a consequence of discerning the brutal reality of some real systems. Therefore, it is important to move from the human rights contained in the works of the legal doctrine to positive regulation of human rights of the disabled at the international and then national level.

Moving to the Polish legal system and the discussed competition of values, it should be noted that, apart from the Preamble to the Constitution of the Republic of Poland, the obligation to protect national heritage is stipulated in Art. 5 of this document which provides, among others, that "the Republic of Poland shall (...) safeguard the national heritage and shall ensure the protection of the natural environment pursuant to the principles of sustainable development." Moreover, Art. 6 clause 1 stipulates that the "Republic of Poland shall provide conditions for the people's equal access to the products of culture which are the source of the Nation's identity, continuity and development." Obligations to persons with disabilities are provided for in Art. 69 of the Constitution of the Republic of Poland in the following wording: "Public authorities shall provide, in accordance with statute, aid to disabled persons to ensure their subsistence, adaptation to work and social communication.”

5 Ternon, Y., Helman, S., Eksterminacja chorych psychicznie w III Rzeszy. Od teoretyków narodowosocjalistycznych do praktyków z SS. Państwowy Zakład Wydawnictw Lekarskich, Warszawa, 1974, p. 31.

${ }^{6}$ Ibidem, p. 14 et seq., 321 
The inherent and inalienable dignity of the person shall constitute a source of freedoms and rights of persons and citizens. It shall be inviolable. The respect and protection thereof shall be the obligation of public authorities" as stipulated in art. 30 of the Constitution. Recognition that humanity and dignity are inextricably linked is the starting point for the formulation of human rights. John Paul II believes that "the dignity of the human person is a transcendent value, always regarded as such by all who sincerely seek the truth. Indeed, the whole history of mankind must be interpreted in the light of this certainty." Human dignity is closely related to natural law and human rights.

A distinction is made between human dignity and personal dignity. While the latter can be lost, the former is inalienable. It is a characteristic that defines every human being. It describes a special human property. Dignity is identified with the value of a human being in general. It is an expression of human nature. It is not subject to gradation. It is tantamount to humanity. ${ }^{8}$ It is granted in the same way to every human being, also in relation to other people. It precedes the man-made legal order. Dignity is the natural law that people receive with their nature. ${ }^{9}$ Disabled people -including those mentally retarded-also have this inalienable trait of dignity. Article 30 of the Constitution of the Republic of Poland stipulates that "the inherent and inalienable dignity of the person shall constitute a source of freedoms and rights of persons and citizens. It shall be inviolable. The respect and protection thereof shall be the obligation of public authorities." The legislator appreciated the importance of human dignity, raising it to the rank of a constitutional norm. Moreover, as stipulated in the Preamble to the Polish Constitution, all who apply the Constitution for the good of the Third Republic, shall do so "paying respect to the inherent dignity of the person." Human dignity is the source of human rights and the guarantee that these rights will be respected.

Human rights are closely related to natural law. Often the enactment of the rights of persons with disabilities is a condition for the exercise of their right to life. An example of such a situation is the right of a disabled person to live in an accessible physical environment. ${ }^{10}$ Definitions of human rights are related to different concepts of the human being, philosophy and law. These rights are justified through the prism of morality or the laws of nature. Human rights are the specific expression of values that need no justification ${ }^{11}-$ such as the right to life. Positive law does not cre-

7 Jan Pawee II, Oredzie na światowy dzień pokoju, 1999. [quoted from :] Rynio, A., Solidarność w nauczaniu Jana Pawta II. Wybór tekstów. Fundacja Servire Veritati Insty tut Edukacji Narodowej, Lublin, 2005, p. 65.

${ }^{8}$ Cf. ibidem, pp. 103-104. KrąPIEc, M.A., Cztowiek i prawo naturalne. Dzieta X. Wydawnictwo KUL, Lublin, 1993, p. 140.

9 Cf. Kość, A., Podstawy filozofii prawa. "Petit”, Lublin, 2001, p. 192.

${ }^{10}$ Cf. Sienkiewicz, T., Prawo cztowieka niepetnosprawnego do życia w środowisku uksztattowanym funkcjonalnie. Wydawnictwo Polihymnia, Lublin, 2004, pp. 21-28.

${ }_{11}$ Cf. Dutkiewicz, P., Problem aksjologicznych podstaw prawa we wspótczesnej polskiej filozofii i teorii prawa. Wydawnictwo Uniwersytetu Jagiellońskiego, Kraków, 1996, p. 88. 
ate human rights, but at best affirms and protects them. ${ }^{12}$ "The purpose of human rights is to protect the citizen from the state (status negativus), to ensure his political participation (status activus), as well as provide him with social or even cultural benefits (status positivus). ${ }^{13}$ In an administrative-and-legal relation, this protection represents an important value, because the relation is characterized by inequality of the parties." The disability of a client at an office renders this inequality even deeper.

Human rights have three basic characteristics: universality, inalienability and inviolability. This entails that they do not have their source in state regulations.

Theories of human rights are connected with theories of the law of nature. The theories of natural law, according to Kość, can be broadly divided along the lines of four main points of view:

1) Theories which require that the principles or norms of natural law have immutable, universal and timeless validity (an absolute, static natural law), and theories that postulate that natural law has only temporal, situational, and hence variable validity (variable, dynamic natural law);

2) Theories that cover entire, more or less closed, systems of norms of natural law (natural law systems), and others that only cover common principles, treating them as natural law (natural law principles);

3) Theories that are based on the diverse bases of validity of natural law: the order of being, the nature of the human being, the nature of things, the principles of justice;

4) Theories that consider natural law to be valid and those for which natural law is merely a conceptual idea, but an obligatory law of duty, i.e, the law that gives effect to positive law. ${ }^{14}$

Not so long ago, the socialist doctrine rejected all non-legal grounds for civil rights. In the Marxist tradition, human rights were associated with human duties, with the the latter having primacy over the former. ${ }^{15} \mathrm{~A}$ democratic state of law cannot make the incorporation of human rights in its legislative order contingent upon positive law. In accordance with Article 2 of the Polish Constitution, the Republic of Poland is "a democratic state ruled by law and implementing the principles of social justice."

An interesting concept of human rights has been presented by Höffe. In his view, human rights have a chance to play a role in commutative justice (justice in exchange). Human rights involve reciprocity (exchange) of rights and duties. "Only when I receive from others benefits that must be reciprocated, does the responsi-

12 Cf. ibidem, pp. 88-89. Höffe O., Etyka państwa i prawa. Wydawnictwo Znak, Lublin, 1992, pp. 65-66.

${ }_{13}$ Zob. Höfre, O., op. cit., p. 99.

${ }_{14}$ Kość, A., op. cit., p. 255.

15 See. Dutkiewicz, P., op. cit., pp. 91-93. 
bility of a human being rest on me. And inversely, I have the human right when I actually provide a benefit that requires mutual exchange of benefits.

A situation like this takes place where there is an interest that cannot possibly be renounced, which can only be achieved by mutual effort. One is then no longer free to say whether they accept the exchange or not. When interests exclude the possibility of resignation, then the entities cannot but cooperate; one cannot withdraw from an exchange of this type. ${ }^{16}$

The rationalist theory of natural law derives from the belief in the unchangeable nature of man. It postulates that, first, one must find out what the existing order of human existence is and then follow the rules determined by this order. ${ }^{17}$ The order of human existence gives rise to the laws of nature which are human rights.

An interesting view of the laws of nature has been presented by Ziembiński. According to him, the concept of laws of nature in the broad sense should be understood as including all "concepts of law as a set of norms, which assume that valid legal norms are norms that have not been established or recognized as valid by a state organization, even if such recognition only means that the organization sanctions the overstepping of those norms. ${ }^{18}$

A document that is of fundamental importance for the protection of human rights is the United Nations' Universal Declaration of Human Rights of 1948, which assumes that human dignity is the basis of human rights. Human dignity is independent of the will of a state or an individual. Dignity was in fact the only concept accepted by all negotiators of the Declaration. ${ }^{19}$ Human dignity is inherent and inalienable. It does not depend on the degree of a person's physical or mental fitness. It is the foundation of justice. If a state is to be fair, dignity must be taken into account in the legislative process and statutory interpretation. ${ }^{20}$

The rights of people with disabilities are included in the Charter of the Rights of Persons with Disabilities. It is a resolution of the Sejm of the Republic of Poland, which constitutes a legal guideline for legislators to implement the principles of social justice with regard to people with disabilities (the above mentioned resolution of the Polish Sejm does not constitute a source of universally binding law in Poland). The norms of positive law which enact the rights of the disabled, are found in various legal acts in many domains of life, because the life of a person with a disability, just as the life of a fully functional or abled persons, is not homogeneous.

The resolution does not contain a closed catalogue of the rights of persons with disabilities, but instead highlights those rights which are particularly important from the point of view of the disabled person. These include the right to access to goods and services, the right of access to treatment and medical care, the right

16 HöfFe, O., op. cit., p. 110.

17 See Kość, A., op. cit., p. 186.

18 Ziembiński, Z., Wstęp do aksjologii dla prawników. Wydawnictwo Prawnicze, Warszawa, 1990, p. 139.

${ }_{19}$ Cf. ibidem, p. 95.

${ }^{20}$ Cf. ibidem, pp. 102-103. 
to access to social rehabilitation, the right to education, the right to assistance in obtaining qualifications, the right to work, the right to social security, the right to life in the environment without functional barriers, the right to have an autonomous representation of one's own group, the right to full participation in public, social, cultural, artistic and sports life as well as in leisure and tourism.

In $₫ 1$ of the Charter of the Rights of Persons with Disabilities, the Sejm stated that these persons "have the right to lead an independent and active life and may not be discriminated against ... this in particular means the right of people with disabilities to ... live in an environment free from functional barriers, in particular:

- Free access to offices, polling stations and public facilities,

- Free movement and general use of means of transport,

- Free access to information,

- Opportunities for interpersonal communication.”

Another important norm, from the point of view of administrative law, is the norm provided for in the above-mentioned Charter which stipulates that the disabled have the right to participate fully in public and social life.

Persons with disabilities should receive special protection from a just law-abiding state, as they are society's weaker members. By virtue of dignity enjoyed by every human being, they have the same right to life and development as fully functional individuals. One element of social justice is the system of equal opportunities which guarantees that weaker members of society have the same opportunities as strong individuals. ${ }^{21}$ Unfortunately, the rights of people with disabilities are not fully or consistently exercised. It is sufficient to note, in connection with the fundamental and inalienable right to life, which is the right of every human being, including a disabled person, that the principles cited above are clearly violated in Polish legislation concerning grounds for abortion. While Article 38 of The Constitution of the Republic of Poland stipulates that The Republic of Poland shall ensure the legal protection of the life of every human being, ${ }^{22}$ the Polish law sanctions inequality in the possibility of exercising one's right to life as early as at the stage of fetal life. ${ }^{23}$ It is worth noting, however, that if a state does not unconditionally respect the right to life of every human being-irrespective of their weaknesses, disabilities, or usefulness- then it does not guarantee the right to life that is inherent to every human being ${ }^{24}$ to any of its citizens. The state does not grant

${ }^{21}$ Cf. Styczeń, T., Wprowadzenie do etyki. TN KUL, Lublin, 1995, p. 193, in the context of the right of weaker (unborn) members of society to life.

22 Cf. Wiśniewski, L., Wolności i prawa osobiste w Konstytucji RP z 1997 roku i w prawie międzynarodowym. "Terra," Poznań, 1998, p. 7.

${ }^{23}$ On the grounds for permissibility of termination of pregnancy in the Polish law, see Art. 4a of the Act of 7 January 1993 on Family Planning, Human Embryo Protection and Conditions of Permissibility of Abortion (Journal of Laws No.133, item 78 with later amendments).

${ }^{24}$ Cf. Strczeń, T., op. cit., p. 192. 
this law, but instead recognizes and affirms it. ${ }^{25}$ An unconditional acceptance of the right to life should be part of our legal order, because "it is only when none of the littlest ones has to fear our democracy, that we all will not have to worry about the shape of our democracy. ${ }^{26}$ "The debate that sometimes takes place in various European countries about the acceptability of abortion or euthanasia is actually a debate about the philosophy of human life adopted in the legislation of those countries and the primacy of the right to comfort (quality of life) over the right to life or vice versa.

The Convention on the Rights of Persons with Disabilities (Journal of Laws of 2012, item 1169), promulgated into Polish law by the Act of 15 June 2012 on the Ratification of the Convention on the Rights of Persons with Disabilities drawn up in New York on 13, December 2006 (Journal of Laws item 882) recognizes the human right to live in an environment free from accessibility barriers. This is stipulated in Article 9.

The right to live in an environment free from accessibility barriers enables a person with a disability to exercise their right to life. To the fully functional members of society, this Article guarantees appropriate living conditions (comfort) or is an element of the right to safety (e.g. fire safety). Living in an environment free from accessibility barriers is one of the human rights of the disabled that follows also from the principles of social justice. It was expressly stated in Article 1 clause 8 of the Charter of the Rights of Persons with Disabilities approved by the resolution of the Sejm of the Republic of Poland of 1 August 1997 (Official Gazzette of the Republic of Poland No. 50, item 475). Architectural, urban, transport, communication and technical barriers make it difficult, and often impossible, for people with disabilities to enjoy the right to life and to meet their needs on a par with the abled. The problem of overcoming accessibility barriers affects not only people with motor dysfunctions, but also people who are blind, visually impaired, deaf, hearing impaired, mentally handicapped, or affected by cardiovascular, respiratory and other defects. The circle of people who are interested in living a life without accessibility barriers is large then.

A disabled person moving in a wheelchair will consider a lack of an elevator in the apartment block in which they live an architectural barrier The daily self-service activities, which abled people perform automatically not giving them much thought, can sometimes be a challenge to a person with a disability that is beyond their capabilities. Accessibility barriers in disabled people's environment can prevent social and medical rehabilitation, make it impossible for them to get a job and meet their basic life needs. A person with a disability, separated from the world by a kind of obstacle course, is at the mercy of third parties, while often they could easily meet their needs themselves, were their surroundings better adapted to

${ }^{25}$ Cf. ibidem, p. 198.

26 Ibidem, p. 199 
their capabilities. The state should strive to eliminate accessibility barriers, because, even though their removal often requires substantial financial outlays, an inclusively designed environment reduces the costs society has to bear in other areas, such as social assistance. It is impossible to neglect the positive effects that removal of such barriers also has on the psychological well-being of the disabled.

It should be noted that the actual application of the right of a disabled person to live in an environment free from accessibility barriers is the basis for the exercise of other human and civil rights. The right of disabled persons to access goods and services cannot be exercised if, for example, a store in which they wish to do their shopping has too narrow a door to accommodate a wheelchair. In the same way, the right of access to treatment and medical care cannot be used in a hospital that is not disabled-friendly. Similarly, access to social rehabilitation may be limited when, for example, there are no funds for adapting rooms for occupational therapy workshops to the needs of the handicapped. The right to education or the right to assistance in obtaining qualifications cannot be exercised in the absence of adequate school building conditions, which unfortunately is the case in a large part of Polish schools. For the same reason, the right to work may remain just a postulate, considering that few work sites apart from supported employment establishments, are accessible to people with disabilities and not many new, suitably adapted facilities are being opened. The right to full participation in social, cultural, artistic, sport and leisure activities and tourism may remain in the sphere of declarations without appropriately arranged spaces and technical facilities. The examples can be multiplied endlessly.

For many years, housing estates, communication routes, and public buildings had been designed without paying attention to the needs of the handicapped, while the arrangement of space is an important element influencing the quality of life of those persons. Space should be developed and arranged keeping in mind the criteria of accessibility, recognizability and usability. ${ }^{27}$ The actual application of these criteria is the exercise of the right to life without accessibility barriers.

The requirements concerning spatial planning that takes into consideration the needs of people with disabilities as well as the preservation of cultural heritage can be found in the legal definition of spatial order. Whenever the Act on Spatial Planning and Land Use Management makes reference to "spatial order," "this is to be understood as a configuration of space that creates a harmonious whole and takes into account, in a structured way, all the functional, socio-economic, environmental, cultural and structural-and-aesthetic conditions and requirements" (Article 2 clause 1). This Act requires that spatial planning and land use management activities should take account of numerous important conditions, among which are "the requirements for the protection of cultural heritage, monuments and modern cultural assets" and "the requirements for the protection of health and

${ }^{27}$ Ostrowska, M., Cztowiek a rzeczywistość przestrzenna. Oficyna Wydawnicza Nauka i Życie, Szczecin, 1991, p. 219. 
safety of people and property and the needs of persons with disabilities" (Article 2, clauses 4 and 5). There are also cases in which the Polish law requires co-operation between the Provincial Heritage Conservation Officer and local government bodies in determining land use management rules for the area under the administrative control of a given local government. For example, when a borough/town/ city council has passed a resolution on preparing a zoning study, the borough leader (wójt), the town mayor (burmistrz) or the city mayor (prezydent miasta) "asks for expert opinions on the solutions adopted in the study," including the opinion of a "competent Provincial Heritage Conservation Officer" (Article 11 item 6 point c). After the council has passed a resolution on preparing the local zoning plan, the borough leader, town mayor or city mayor, among the many actions set out in Art. 17 of this Act, moves for the plan to be reviewed and accepted by "the competent Provincial Heritage Conservation Officer with regard to building and land development." Before the council passes a resolution on the principles and conditions of arranging street furniture, billboards, advertising equipment and fences, their dimensions, quality standards and types of construction materials which they can be made from, the borough leader/mayor is obliged to immediately have the $\mathrm{draft}$ resolution reviewed, also by the Provincial Heritage Conservation Officer "with regard to building and land development" (Article 37b clause 2 item 4). According to Art. 38b clause 2 item 2 point c, "The Provincial Board, before submitting the draft landscape audit for adoption by the Provincial Assembly" "will consult the draft," among others, with the Provincial Heritage Conservation Officer. According to Art. 53 clause 4 item 2, "Decisions referred to in Art. 51 clause 1 (on the location of public purpose investments), will be issued upon review by the Provincial Heritage Conservation Officer regarding sites and buildings protected by conservation measures referred to in Art. 7 of the Act of 23 July 2003 on the Protection and Guardianship of Monuments, and sites and buildings included in the Borough Register of Listed Structures."

The construction-related aspects of the competition that exists between heritage value and accessibility needs are manifested in procedures concerning:

1. Granting of a building permit issued under the Construction Law Act, when works are to be carried out at a listed building or in its vicinity;

2. Execution of construction works under a pre-construction notification as defined in the Construction Law Act, when works are to be carried out at a listed building or in its vicinity;

3. Granting a permission to conduct construction works at a listed structure under the Protection and Guardianship of Monuments Act;

4. Removal of accessibility barriers (primarily architectural barriers) in connection with the individual needs of people with disabilities under the Act on occupational and Social Rehabilitation and Employment of Persons with Disabilities;

5. Obtaining the legal status of a supported employment establishment, as defined by the provisions of the Act on Occupational and Social Rehabilitation and Employment of Persons with Disabilities; 
6. Obtaining the legal status of an occupational activity establishment, as defined by the provisions of the Act on Occupational and Social Rehabilitation and Employment of Persons with Disabilities;

7. Obtaining the status of a rehabilitation centre, as defined by the provisions of the Act on Occupational and Social Rehabilitation and Employment of Persons with Disabilities.

This is not an exhaustive catalogue of examples. It should be added in passing that important provisions regarding the adjustment of newly constructed buildings to the needs of people with disabilities (especially public buildings and multi-family buildings which are designed to be used by many people) can be found in the Regulation of the Minister of Infrastructure of 12 April 2002 on the Technical Conditions of Buildings and their Location (uniform text: Journal of Laws of 2015, item 1422) ${ }^{28}$.

There are many situations in which the human right of a disabled person to live in an accessible environment and the obligation to preserve historical heritage must be taken into account in considering evidence or interpreting the law. The Construction Law Act (hereinafter referred to as: Construction Act) refers to the above-mentioned criteria in many places. The obligations toward people with disabilities are already mentioned in the provisions regarding the design and construction of civil engineering structures. Pursuant to Art. 5 clause 1 item 4 of the Construction Act: "A structure as a whole and its individual parts, together with related construction equipment, shall be designed and constructed, taking into account the anticipated period of use, in the manner specified in the relevant provisions, including technical and building regulations and principles of technical knowledge, in order to secure [...] necessary conditions for use of public facilities and residential multi-family housing by persons with disabilities, and in particular persons using wheelchairs." The right of accessibility of buildings to disabled people is mentioned already with reference to the legal requirements regarding the contents of the project itself. According to Art. 34 clause 3 item 2 of the Construction Act, an architectural and construction design describing the function, shape and structure of a building, its characteristics as to energy consumption and environmentalissues, should contain proposals of necessary technical and materials solutions in order to illustrate theprinciples of adapting the structure to its environment, and in relation to structures referred to in Art. 5 clause. 1 item 4 -such a design should also include a description of accessibility of the building to the disabled (4) necessary conditions for the use of public facilities and residential multi-family housing by persons with disabilities, and in particular persons using wheelchairs]. Sometimes, it is necessary to change an approved building design, which often leads to the question whether

${ }^{28}$ Cf. for example $\$ 9-\$ 21$ of the Regulation of the Minister of Labour and Social Policy of 27 November 2007 on Rehabilitation Programmes (Journal of Laws No.230, item 1694 with later amendments). 
the proposed changes are substantial or not. The legislator in Art. 36a clause 1 provides that "Substantial departure from the approved building design or other conditions covered by the building permit shall be admissible only after obtaining a decision changing the building permit from the competent architecture and building administration body." Next, Art. 36a clause 5 item 5 stipulates that "Insignificant departure from the approved building design or other conditions of the building permit shall not require obtaining a decision on amendment of the buildingpermit and shall be admissible unless it concerns: ... ensuring the conditions necessary for the object to be used by disabled persons [emphasis mine ].

At times, it is necessary to make exceptions to the application of technical and building regulations, however, in some cases, such exceptions must be made keeping in mind the need to ensure accessibility of buildings to the handicapped as well as heritage conservation requirements. Pursuant to Art. 9 of the Construction Act.

1. In particularly justified cases, the application of technical and building regulations, referred to in Article 7, may be renounced. Such renunciation may not endanger human life or safety of property, while in the case of buildings mentioned in Article 5, clause 1, item 4, it may not restrict the access of disabled people to those buildings, nor shall it cause deterioration of health and sanitary conditions, utility requirements, as well as the state of the natural environment, after fulfilling certain substitutive requirements.

2. Upon receiving an authorisation from the minister, who set forth the technical andbuilding regulations, the competent authority shall, by a decision, either refuse or grant the permit regarding the renunciation of the said regulations.

3. The application to the minister referred to in paragraph 2 , regarding authorization to grant consent for the renunciation of regulations, shall be submitted by a competent authority prior to the issue of the building permit decision. The said application shall contain:

a) A description of the features of the object and, where necessary, the plot or land development design, and if the renunciation may affect the natural environment or the neighbouring real estate, also development designs for these real estate properties, taking into account the existing and projected housing development;

b) Detailed justification of the necessity to renounce the application of the said regulations;

c) Proposals for substitutive solutions;

d) A positive opinion of the Provincial Heritage Conservation Officer in respect of listed buildings and other buildings located in the areas subject to conservation protection;

e) Where necessary, a positive opinion of other authorities concerned.

4. The minister referred to in paragraph 2, may make the issue of permits for the saidrenunciation contingent upon the fulfilment of additional requirements" [emphasis mine]. 
At the same time, attention should be paid to the situation in which one norm of the Construction Act allows action under a pre-construction notification while another, lex specialis, requires a building permit. Pursuant to Art. 29 clause 1 item 18 of the Construction Act "The construction of [...] ramps designated for disabled persons [...] shall not require a building permit." Simultaneously, clause 4 of the same Article stipulates that said works.

1) require a building permit when carried out at a listed structure,

2) or the notification referred to in Art. 30 clause 1 when carried out in a listed conservation area.

-with the reservation that the building permit and the pre-construction notification must be accompanied by a permit from the competent Provincial Heritage Conservation Officer, issued on the basis of regulations on the protection and guardianship of monuments." This refers to the permit issued under Art. 36 clause 1 of the Act on the Protection and Guardianship of Monuments, which stipulates that, among many types of permits, the execution of construction works at a listed building or in its vicinity requires a permit from the Provincial Heritage Conservation Officer (Article 36 clause 1 items 1 and 2 of the Act on the Protection and Guardianship of Monuments). The requirement that certain construction activities performed at a civil engineering structure must be accepted by heritage conservation authorities is mentioned in Art. 39 of the Construction Act:

1. The performance of construction work concerning a listed structure or a listed conservation area shall be subject to obtaining, prior to issue of the building permit decision, the permit for conducting the said work issued by the competent Provincial Heritage Conservation Officer.

2. A permit to demolish a listed structure may be issued after obtaining a decision of the Chief Heritage Conservation Officer, acting on behalf of the minister competent for culture and protection of national heritage, on removal of the said object from the register of monuments.

3. With regard to buildings and structures which are unlisted nationally but are covered in a Borough Register of Built Heritage, the building permit or the permit to demolish a structure shall be issued by thecompetent authority in consultation with the Provincial Heritage Conservation Officer.

4. The Provincial Heritage Conservation Officer shall be obliged to express his opinion regarding the application for a permit to build or demolish the structures referred to in paragraph 3 within 30 days from the day when it was served. Failure to express an opinion within this time limit shall be considered as lack of objections as to the design solutions presented in the application... [emphasis mine].

As the regulations quoted above show, the right of people with disabilities to free access to buildings and structures and the right of the national community to preserve the national heritage are intertwined, and a public administration body 
has to seek a balance of obligations between the legitimate interest of a party and social interest. With regard to decisions on issuing a building permit, the register of building permit applications and building permit decisions includes information on "arrangements with the Provincial Heritage conservation Officer concerning the date of sending the documents to the Officer, date of receipt of the review and the number of days required for the review of documents "(Art. 86b clause 3a item 2point i of the Construction Act).

The competent authority shall carry out, when summoned by the investor, a mandatory inspection of the construction in order to ascertain that it was conducted in compliance with the approvals and conditions specified in the building permit" (Article 59a clause 1 of the Construction Act). This inspection includes verification of:

1) Compliance of the building with the plot development or land development design;

2) Compliance of the building/structure with the architectural and construction design in terms of $[. .$.$] ensuring the conditions necessary for the building$ structure to be used by disabled persons, in particular persons using wheelchairs - with respect to public buildings and multi-family residential buildings" (Article 59a clause 2 items 1 and 2 point $\mathrm{f}$ of the Construction Act).

The legislator has also taken account of situations in which a building or structure is not suitable for renovation. A problem arises when the building/structure is a historical monument. Pursuant to Art. 67 clauses 1-4 of the Construction Act:

1. If an unused or unfinished building is not suitable for renovation, reconstruction or completion, the building authority shall issue a decision ordering the owner or administrator to demolish the building and put the site in order. The said decision shall specify the dates of commencement and completion of these activities.

2. The provisions of clause 1 do not apply to listed buildings and structures.

3. In relation to unlisted buildings subject to conservation protection under a local spatial development plan, the decision referred to in clause 1 shall be issued by building supervision authorities subject to prior agreement with the Provincial Heritage Conservation Officer.

4. The Provincial Heritage Conservation Officer is obliged to express his opinion within 30 days. Failure to do so within the time allowed shall be considered an agreement."

To resolve a conflict of values is to proceed according to the procedure established in, among others, the Code of Administrative Procedure. Currently Polish administrative law is mainly based on so-called first generation of administrative procedures, although it is gradually being modified. Likewise, the construction permit granted on the basis of the Construction Law Act (Art. 28), and the permit for construction works at a monument or in its surroundings, granted on the 
basis of the Law on Protection and Guardianship of Monuments (Art. 36 , clause 1 , item 1 and 2) seem to be the fruit of a first generation of procedures. However, in the case of determining the scope of application of values pertaining to the right of a disabled person to live in a functionally accessible environment and the protection of immovable monuments, it would be worth considering if, in the Polish administrative law on rendering administrative decisions pursuant to construction law and protection of monuments, there are such aspects of the discussed issue which could constitute a basis for applying procedures similar to those which were described by Barnes as a third generation of administrative procedures. ${ }^{29} \mathrm{I}$ am purposefully using the term "similar to" with reference to those proceedings, since the Polish law shall oblige a public administration body to strictly obey the law, and all types of negotiations and reconciliation of standpoints are limited by law. Moreover, granting a construction permit pursuant to the Construction Law Act, and permit for construction works at a listed structure/building (or in its surroundings) pursuant to the Act on the Protection and Guardianship of Monuments exercise norms of substantive law. Both decisions are rendered by two different public administration bodies (starosta, Provincial Heritage Conservation Officer). Pursuant to Art. 7 of the Constitution of the Republic of Poland "The organs of public authority shall function on the basis of, and within the limits of the law," and pursuant to Art. 6 of the Code of Administrative Procedure "Public administration bodies shall act in accordance with the law." In many cases law refers to extralegal

29 Barnes, J., “Towards a Third Generation of Administrative Procedures,” First draft -2016 Conference on Comparative Administrative Law April 29-30, 2016, https://law.yale.edu/ system/files/area/conference/compadmin/compadmin16_barnes_towards.pdf [01.11.2017], pp. 2-3: “... the third generation of administrative procedures consists of a collaborative method for making individual decisions and for rules and regulations, in which other administrative or private actors not only collaborate in varying degrees in the process to gather the relevant information, but also participate in one or more of the procedural stages, and in which these procedures are open to develop new solutions that are not previously foreseen by the law (i.e., environmental impact assessment, strategic environmental assessment procedures in the EU, or environmental permit procedures2). Rules and decisions to be made are not discovered in the law, but rather invented or created in the procedure. Procedural requirements may be imposed to private parties participating in the regulatory cascade." Cf. BARNES, J., "Introduction reform and innovation in administrative procedure." http://en.globallawpress.org/wp-content/uploads/Book2IntroENG.pdf [01.11.2017]. Cf. BArNEs, J., "Tres generaciones del procedimiento administrativo.” Derecho PUCP. Revista de la Facultad de Derecho No 67, 2011, http://revistas.pucp.edu.pe/index.php/derechopucp/article/view/2992/3508 [05.11.2017]. Cf. BARnes, J., "Procedimientos administrativos de tercera generacion,” https://revistas-colaboracion. juridicas.unam.mx/index.php/opera-prima-derecho-admin/article/viewFile/1428/1329 [06.11.2017]; Cf. BARNÉs VÁZqUEZ, J., "El procedimiento administrativo y el gobierno electrónico," http://repositorio.gobiernolocal.es/xmlui/bitstream/handle/10873/968/claves12_08_barnes.pdf?sequence=1, pp. 95-100, [06.11.2017]. Cf. KMIECIAK, Z., "Idea procedur administracyjnych trzeciej generacji (na przykładzie postępowania w sprawie dofinansowania projektów w ramach programów operacyjnych)," Państwo i Prawo 5/2015. Cf. Ćwiklińska, M., "Trzy generacje postępowania administracyjnego a Kodeks postępowania administracyjnego," ActaUniversitatisLodziensis. Folia Iuridica 75, 2015, http://dspace.uni.lodz.pl:8080/xmlui/bitstream/handle/11089/17022/4-041_050-\%C4\%86wikli\% $\mathrm{C} 5 \% 84$ ska.pdf?sequence $=1 \&$ isAllowed $=\mathrm{y}$. 
systems or does not directly specify criteria for evaluation of evidence in evidentiary process, before rendering the decision. Such situation occurs in the case of a permit for construction works at a listed structure/building, where the procedure specifies the body rendering an administrative decision (Provincial Heritage Conservation Officer), the formal grounds for initiation of administrative proceedings, formalization of an administrative decision, but there are no grounds for evaluation of evidence. Right there arises an opportunity to apply a procedure of evaluation of the aforementioned evidence in a way similar to application of a third generation of administrative procedures, whereas public administration bodies shall be constantly bounded by law. This bounding is necessary, since a procedure shall be aimed at decision equity and legal safety of both a public administration body and an administratively and legally subordinate entity.

Equity of an administrative decision ${ }^{30}$ cannot be considered without application of a procedure that shall provide a resolution of proceedings which might be considered equitable. Even the most noble premises might be undermined by the procedure whose aim cannot be considered equitable. Modus operandi might be contrary to the aim. The procedure, i.e. a manner of achieving the final effect in a form of an administrative decision, might or might not support the equity formula applied in a given legal system. This is also manifest in a procedure that has features that make it possible to realize the equity formula. If a public administration body is endowed with competitive values, a different manner of formalization of grounds and the extent of formalization of an administrative decision that goes beyond basic elements, indicated in Art. 107 of the Code of Administrative Procedure as applicable within the same legal condition, there occurs a situation which might exert a particularly adverse effect on the opportunity to reach an equitable decision.

A public administration body being bound by law is not necessarily tantamount to leaving a party in the proceedings in an entire dependence on the aforementioned organ. A number of rules included in the Code of Administrative Procedure encourage flexibility of procedure and ensure legal safety of a party. The aforementioned rules include the rule of taking all necessary steps to clarify the facts of a case and to resolve it, not only by request of a party but also ex officio, having regard to the public interest and the legitimate interests of members of the public (Art. 7 of the Code of Administrative Procedure), the rule of cooperation of public administration bodies during the proceedings, to the extent necessary to clarify the facts and legal status of the case, having regard to public interest and the legitimate interests members of the public and effectiveness of proceedings, by means of measures adequate to character, circumstances and complexity of the case (Art. 7b of the Code of Administrative Procedure), the rule of conducting proceedings in such a way as to increase the trust of citizens in public authority, having regard to the rules of proportionality, impartiality and equal treatment (Art. $8 \$ 1$ of the Code of Administrative Procedure). "Public administration bodies are required to

${ }^{30}$ Cf. Sienkiewicz, T., Racjonalność decyzji..., op. cit. 
provide full and proper information to the parties regarding the factual and legal circumstances which may affect the establishment of their rights and the obligations that are the subject of the administrative proceedings. The bodies shall take care to ensure that parties and other persons involved in proceedings do not suffer any loss owing to ignorance of the law and shall therefore provide the necessary clarifications and advice" (Art. 9 of the Code of Administrative Procedure). "Public administration bodies are required to ensure that parties are actively involved in each stage of proceedings and they shall allow the parties to express an opinion on the evidence and materials collected and the claims filed", and it is only possible to derogate from this rule when "resolution of the case requires urgent attention because of threats to human life or health or the threat of irretrievable material damage", and such derogation shall be recorded in the case file, by way of annotation (Art. 10 of the Code of Administrative Procedure). Moreover, "Public administration bodies should explain to the parties the basis for the rules used to decide a case, so that a decision may be implemented by the parties without the need for coercive measures" (Art. 11 of the Code of Administrative Procedure). The Code of Administrative Procedure specifies also proceedings aimed to settle disputes. Pursuant to Art. 13 of the Code of Administrative Procedure:

$\$ 1$. Public administration bodies, in cases whose character allows for that, aim for settlement of disputes and establishing rights and obligations which are subject of proceedings in the cases within their competence, and, in particular, by taking steps:

1) to induce the parties who have a conflict of interests to agree a settlement;

2) necessary to conduct mediations.

$\$ 2$. Public administration bodies take all reasonable steps at a given stage of proceedings, which allow for mediation or settlement, and, in particular, provide explanations concerning opportunities and benefits of amicable settlement.

There are also such situations where mediation might be a way of establishing the scope of individual values protected by law. Mediation is applied when character of a case allows for that (the Code of Administrative Procedure Art. 96a-96n). Pursuant to Art. 96a $\$ 3$ of the Code of Administrative Procedure "Aim of mediation is to explain and consider factual and legal circumstances of case, and make arrangements pertaining to resolving it within the existing law, including resolving the case by means of decision or settlement," and its participants might be not only parties involved in the proceedings, but also the body conducting proceeding and party or parties (Art. 96a \$4). "If, as a result of mediation, there are arrangements made pertaining to resolution of the case within the existing law, a public administration body resolves the case according to those arrangements, included in the mediation protocol" (Art. 96n $\$ 1$ of the Code of Administrative Procedure). Having regard to Art. 36 of the Act on the Protection and Guardianship of Monuments, 
there are significant opportunities to apply mediation in the situation when legislator has not directly expressed grounds for evaluation of evidence, but they shall be specified, by means of interpretation of the law, on the basis of a legal definition of monument or a statutory definition of monument protection.

While discussing the issue of competition of values, it needs to be noticed that protection of monument, due to public interest, arises from the definition of monument itself. Polish Act on the Protection and Guardianship of Monuments differentiates between immovable, movable and archaeological monument. The Polish word "zabytek" has a wider context than the English word "monument." In Polish the word "zabytek" does not only mean immovable monument. The law on protection and guardianship of monuments provides a definition of a monument in art 3 point $1-4$.

1) Monument -immovable or movable object or part of group thereof, made by man or connected with man's activity and constituting a testimony to a past era or event, the preservation of which is in the interest of society due to its historical, artistic, scientific or academic value.

2) Immovable monument-immovable object or part or group of objects referred to in point 1 .

3) Movable monument -movable object or part or group of objects referred to in point 1.

4) Archaeological monument -immovable monument constituting surface, underground or underwater remains of human existence or activity, composed of cultural accumulations and works or traces thereof contained in these accumulations, or a movable monument constituting such work. ${ }^{31}$

In addition to this, the legislator, in the title of the Act on the Protection and Guardianship of Monuments differentiates between 'protection' and 'guardianship'. The division into protection of monuments and guardianship of monuments represented a contribution to formulation of critical remarks ${ }^{32}$. Pursuant to Art. 4 of

31 http://www.unesco.org/culture/natlaws/media/pdf/poland/poland_act2302003_entof. pdf [[Access: 06-11-2017 -attention-invalid legal status of the act, but the definition of monument is currently acceptable] Art. 3

1) Monument -immovable or movable object or part of group thereof, made by man or connected with man's activity and constituting a testimony to a past era or event, the preservation of which is in the interest of society due to its historical, artistic, scientific or academic value;

2) Immovable monument -immovable object or part or group of objects referred to in point 1 ;

3) Movable monument -movable object or part or group of objects referred to in point 1;

4) Archaeological monument -immovable monument constituting surface, underground or underwater remains of human existence or activity, composed of cultural accumulations and works or traces thereof contained in these accumulations, or a movable monument constituting such work.

32 Normative differentiation between "protection" and "guardianship" has been subject to criticism -cf. ZeIdLer, K., O wtaściwy ksztatt stużby ochrony zabytków w Polsce. Postulaty de lege 
the aforementioned Act, the protection of monuments consists in, in particular, undertaking activities, by the public administration bodies, with the aim to:

1) Ensure legal, organizational and financial conditions that enable permanent preservation of monuments as well as their development and maintenance;

2) Prevent threats that may decline monuments' value;

3) Foil the destruction or improper use of monuments;

4) Counteract thefts, getting lost, or illegal export of monuments;

5) Check the state of preservation and the use of a monument;

6) Plan and develop the space, and shape the environment with the consideration of protection tasks.

Definition of guardianship of monuments is included in Art. 5 of the Act on monuments. As defined in the provisions thereof, the guardianship of monument by its owner, or its proprietor consists, in particular, in ensuring conditions for:

1) Scientific research and documentation of a monument;

2) Carrying out conservation, restoration and construction works at a monument;

3) Pprotection, and maintenance of a monument and its surroundings in the best possible state;

4) Use of a monument in a way ensuring permanent preservation of its value;

5) Popularization and dissemination of knowledge on a monument, and its historical and cultural significance.

Therefore, having regard to public interest in protection of monuments, legal norms shall be prepared in such a way that monuments are preserved for future generations, and, at the same time, subjective rights of proprietors of monuments are respected. At the same time, there arises the question, which extralegal systems of values, not indicated directly, might be determined within the process of interpretation of concepts 'protection of monuments' and 'guardianship of monuments'. A good example of this type of norms arising from extralegal law is conservational theory, which is not directly mentioned in the Act on the Protection and Guardianship of Monuments. Therefore, it is worth mentioning the rules of the aforementioned theory, according to Rouba, which will be useful in the process of application of many norms of the Act on the Protection and Guardianship of Monuments. "The fundament of contemporary theory of conservation-restoration, developed with difficulty over the centuries, and, in particular, in the last century, is imperative of individual treatment of each monument -based on scientific grounds for deep understanding of its essence, condition, establishing diagnosis and searching for appropriate treatment. The imperative of individual treatment of monument is, by no means, tan-

ferenda. [in:] Gardocka, T., Sobczak, J., (ed.) Prawna ochrona dóbr kultury. Wydawnictwo Adam Marszałek, Toruń, 2009, p. 34. 
tamount to arbitrariness of treatment. It means searching for solutions that allow for preserving monument for future generations in the possible unchanged condition, together with all its values" 33 [emphasis mine]. Rouba mentions seven rules of conservation, such as the following:

1) Primum non nocere;

2) Maximum respect for original substance of monument and all the values (material and non-material) thereof;

3) Minimum of essential interference (restraining from unnecessary actions);

4) In accordance with the above, this (and only this) that has a destructive impact on the original, shall be removed;

5) Clarity and differentiability of interference, and their aesthetic subordination to the original (non-competitiveness);

6) Reversibility of methods and materials;

7) Conducting all the works to the best of our knowledge and at the highest level. ${ }^{34}$

Therefore, legal system shall be endowed with such norms that allow for acting in accordance with rules of conservation. The Act on the Protection and Guardianship of Monuments does not directly refer to theory of conservation, which constitutes, for an office employee writing, e.g. an administrative decision, a difficulty in formulation of factual and legal resolution (see Art. 107 of the Code of Administrative Procedure).

Rules of conservation theory refer to actions on the object - monument itself, but values of regulation should be searched for in a much broader context, not only in the monument itself. In the center of axiology of the Act on the Protection and Guardianship of Monuments there is indeed a man and enhancing his relationship with national community. In the center of axiology of the Act on the Protection and Guardianship of Monuments, there is respect for human creativity that constitutes demonstration of humanity and demonstration of actions within the given culture related to a given social group. That culture cannot be ignored while establishing limits of legal protection of other goods protected by law, since it constitutes a basis for strengthening national identity. Despite the obligation of cooperation between public administration bodies in the course of the proceedings, to the extent necessary to clarify factual and legal state of the case, having regard to public interest and legitimate interest of the public, as well as efficiency of proceedings, by means of measures adequate to character, circumstances and complexity of the case (Art. 7a of the Code of Administrative Procedure), it is worth noticing the necessity for novelization of regulations pertaining to relationships of architec-

33 Rouba, B.J., Teoria w praktyce polskiej ochrony, konserwacji i restauracji dziedzictwa kultury. [in:] Szmygin, B. (ed.) Wspótczesne problemy teorii konserwatorskiej w Polsce. Wydawnictwo Politechniki Lubelskiej, Warszawa, Lublin, 2008, p. 102.

${ }^{34}$ See ibidem, p. 107. 
ture and construction administration bodies mentioned in Art. 28 of the Construction Law Act, in particular starosta and Provincial Heritage Conservation Officer, in such a way that in certain cases it is not necessary to issue two administrative decisions pertaining to one object, one of which is issued by Provincial Heritage Conservation Officer and another one by starosta. It would be necessary to ensure that, during a single proceeding, with cooperation of both interested bodies and party (parties), only one administrative decision is issued. The author believes that nowadays, during the proceedings before Provincial Heritage Conservation Officer aiming at obtaining a permit for construction works at a listed monument or in the surroundings thereof, competition of discussed values might be resolved by means of rules of conservation theory and administrative procedure mentioned in the Code of Administrative Procedure that allows to reach compromise, by means of mediation, between the scope of the right of a disabled person to live in a functionally accessible environment and the obligation to protect monuments.

Recibido: febrero de 2018. Aceptado: abril de 2018 


\section{BIBLIOGRAPHY}

\section{LEGAL DOCUMENTS}

1) Konwencja o prawach osób niepełnosprawnych sporządzona w Nowym Jorku dnia 13 grudnia 2006 r. (Dziennik Ustaw [Dz.U. - Journal of Laws] 2012, item 1169).

2) Konstytucja Rzeczypospolitej Polskiej z dnia 2 kwietnia 1997 r. (Dz. U. No. 78, item 483 with later amendments).

3) Powszechna Deklaracja Praw Człowieka przyjęta i proklamowana przez Zgromadzenie Ogólne Organizacji Narodów Zjednoczonych w dniu 10 grudnia 1948 roku.

4) Ustawa z dnia 14 czerwca $1960 \mathrm{r}$. Kodeks postępowania administracyjnego (consolidated text: Dz. U. 2013, item 267, with later amendments).

5) Ustawa z dnia 7 stycznia 1993 r. o planowaniu rodziny, ochronie płodu ludzkiego i warunkach dopuszczalności przerywania ciąży (Dz. U. No. 17, item 78, with later amendments).

6) Ustawa z dnia 27 sierpnia 1997 r. o rehabilitacji zawodowej i społecznej oraz zatrudnianiu osób niepełnosprawnych (consolidated text: Dz. U. 2016, item 2046, with later amendments).

7) Ustawa z dnia 23 lipca 2003 r. o ochronie zabytków i opiece nad zabytkami (Dz. U. No. 162, item 1568, with later amendments).

8) Ustawa z dnia 15 czerwca 2012 r. o ratyfikacji Konwencji o prawach osób niepełnosprawnych, sporządzonej w Nowym Jorku dnia 13 grudnia 2006 r. (Dz. U. item 882).

9) Rozporządzenie Ministra Pracy i Polityki Społecznej z dnia 27 listopada 2007 r. w sprawie turnusów rehabilitacyjnych (Dz. U. No. 230, item 1694, with later amendments).

10) Rozporządzenie Ministra Infrastruktury z dnia 12 kwietnia 2002 r. w sprawie warunków technicznych, jakim powinny odpowiadać budynki i ich usytuowanie (consolidated text: Dz. U. 2015, item 1422).

11) Karta praw osób niepełnosprawnych zatwierdzona uchwałą Sejmu Rzeczpospolitej z dnia 1 sierpnia 1997 r. (M.P. [Monitor Polski - Official Gazette of the Government of the Republic of Poland] No. 50, item 475).

\section{REFERENCES}

BARnés VÁzquez, J.. “El procedimiento administrativo y el gobierno electrónico”, http://repositorio.gobiernolocal.es/xmlui/bitstream/handle/10873/968/claves12_08_barnes.pdf?sequence $=1$ [06.11.2017].

BARnES, J., "Introduction reform and innovation in administrative procedure". http://en.globallawpress.org/wp-content/uploads/Book2IntroENG.pdf [01.11.2017].

Barnes, J. "Procedimientos administrativos de tercera generacion”, https://revistas-colaboracion. juridicas.unam.mx/index.php/opera-prima-derecho-admin/article/viewFile/1428/1329 [06.11.2017].

Barnes, J., “towards a third generation of administrative procedures," First draft -2016 Conference on Comparative Administrative Law April 29-30, 2016, https://law.yale.edu/ system/files/area/conference/compadmin/compadmin16_barnes_towards.pdf [01.11.2017]. 
Barnes, J., “Tres generaciones del procedimiento administrativo”, Derecho PUCP. Revista de la Facultad de Derecho No 67, 2011, http://revistas.pucp.edu.pe/index.php/derechopucp/article/ view/2992/3508 [05.11.2017].

ĆwıkııŃska, M., “Trzy generacje postępowania administracyjnego a Kodeks postępowania administracyjnego.” Acta Universitatis Lodziensis. Folia Iuridica 75, 2015.

DutKIEW ICZ, P., Problem aksjologicznych podstaw prawa we wspótczesnej polskiej filozofii i teorii prawa, Wydawnictwo Uniwersytetu Jagiellońskiego, Kraków.

Höfre, O., Etyka państwa i prawa. Wydawnictwo Znak, Kraków, 1992.

Jan Paweł II, Oredzie na światowy dzień pokoju, 1999. [Quoted from:] Rynio, A., Solidarność w nauczaniu Jana Pawta II. Wybór tekstów. Fundacja Servire Veritati Instytut Edukacji Narodowej, Lublin 2005.

KMieciak, Z., "Idea procedur administracyjnych trzeciej generacji (na przykładzie postępowania w sprawie dofinansowania projektów w ramach programów operacyjnych)", Państwo i Prawo 5/2015.

Kość, A., Podstawy filozofii prawa. "Petit," Lublin, 2001.

Krąpiec, M.A., Cztowiek i prawo naturalne. Dzieta X, Redakcja Wydawnictw KUL, Lublin, 1993.

ŁĄCzKowski, W., Granice prawa. [In:] Depo, W., Leszczyński, M., Guz, T., Marzec, P. (eds.), Veritatem in Caritate. Księga Jubileuszowa z okazji 70. urodzin Ksiedza Biskupa Profesora Jana Śrutwy. Wydawnictwo KUL, Lublin 2011.

Łączkowski, W., Ograniczenia prawa stanowionego. [In:] Dębiński, A., Pomorska, A., Smoleń, P. (eds.) W stużbie nauki prawa finansowego. Jubileusz obecności profesora Jana Gtuchowskiego w Katedrze Finansów i Prawa Finansowego Katolickiego Uniwersytetu Lubelskiego Jana Pawta II. Wydawnictwo KUL, Lublin 2010.

Łączkowski, W., Prawo a zmiana ustroju państwa. Wydawnictwo Naukowe Uniwersytetu Adama Mickiewicza, Poznań, 1992.

Ostrowska, M., Cztowiek a rzeczywistość przestrzenna. Oficyna Wydawnicza Nauka i Życie, Szczecin 1991.

RoubA, B.J., Teoria w praktyce polskiej ochrony, konserwacji i restauracji dziedzictwa kultury. [In:] Szmygin, B. (ed.) Wspótczesne problemy teorii konserwatorskiej w Polsce. Wydawnictwo Politechniki Lubelskiej, Warszawa, Lublin, 2008.

Sienkiewicz, T., Prawo cztowieka niepetnosprawnego do życia w środowisku uksztattowanym funkcjonalnie, Wydawnictwo Polihymnia, Lublin, 2004.

Sienkiewicz, T., Racjonalność decyzji administracyjnej. [In:] P. Marzec (ed.), Servire veritati. Księga jubileuszowa zokazji siedemdziesiatych urodzin Profesora Kazimierza A. Ktosińskiego. Wydawnictwo KUL, Lublin, 2011.

Sien KIEWICZ, T. Status cztowieka niepetnosprawnego w prawie administracyjnym. Krajowa Izba Gospodarczo-Rehabilitacyjna, Warszawa, 2006.

Sienkiewicz, T. Status cztowieka niepetnosprawnego w prawie publicznym. Krajowa Izba Gospodarczo-Rehabilitacyjna, Warszawa, 2007.

STYczeń, T., Wprowadzenie do etyki, TN KUL, Lublin, 1995.

Wiśniewski, L., Wolności i prawa osobiste w Konstytucji RP z 1997 roku i w prawie międzynarodowym, “Terra," Poznań, 1998. 
Ternon, Y., Helman, S., Eksterminacja chorych psychicznie w III Rzeszy. Od teoretyków narodowosocjalistycznych do praktyków z SS, Państwowy Zakład Wydawnictw Lekarskich, Warszawa, 1974.

ZDYB, M, "Państwo prawa w perspektywie zaszłości historycznych oraz dokonujących się zmian." [In:] Fundowicz, S., (ed.) Współczesne problemy prawa publicznego. Studia z prawa publicznego, vol. 1, Lublin, 1999.

ZDyв, M., Prawny interes jednostki $w$ sferze materialnego prawa administracyjnego. Studium teoretyczno-prawne. Wydawnictwo Uniwersytetu Marii Curie-Skłodowskiej, Lublin, 1991.

ZeIdler, K., O wtaściwy ksztatt stużby ochrony zabytków w Polsce. Postulaty de lege ferenda. [In:] Gardocka, T., Sobczak, J. (eds.), Prawna ochrona dóbr kultury. Wydawnictwo Adam Marszałek, Toruń, 2009.

Ziembiński, Z., Wstęp do aksjologii dla prawników. Wydawnictwo Prawnicze, Warszawa, 1990. 